\title{
Exploration culturable bacterial symbionts of sponges from Ternate Islands, Indonesia
}

\author{
AGUS TRIANTO ${ }^{1,2, \vartheta}$, OCKY KARNA RADJASA $^{1,3}$, AGUS SABDONO $^{1,2}$, SAKTI IMAM MUCHLISSIN ${ }^{3}$, \\ RACHMAT AFRIYANTO ${ }^{2}$, SULISTIOWATI ${ }^{2}$, SEPTHY KUSUMA RADJASA ${ }^{3}$, PHILLIP CREWS ${ }^{4}$, \\ ERIN MCCAULEY ${ }^{4}$ \\ ${ }^{1}$ Department of Marine Science, Faculty of Fisheries and Marine Science, Universitas Diponegoro. Jl. Prof. Soedarto, SH, Tembalang, Semarang 50275, \\ Central Java, Indonesia. Tel.: +62-24-7474698, Fax.: +62-24-7474698, `email: agustrianto.undip@ gmail.com. \\ ${ }^{2}$ Natural Product Laboratory, Centre for Research and Services, Universitas Diponegoro. Jl. Prof. Soedarto, SH, Tembalang, Semarang 50275, Central \\ Java, Indonesia \\ ${ }^{3}$ Tropical Marine Biodiversity Laboratory, Faculty of Fisheries and Marine Science, Universitas Diponegoro. J1. Prof. Soedarto, SH, Tembalang, \\ Semarang 50275, Central Java, Indonesia \\ ${ }^{4}$ Department of Chemistry and Biochemistry, University of California Santa Cruz. 1156 High Street, Santa Cruz, California, USA
}

Manuscript received: 22 January 2019. Revision accepted: 24 February 2019

\begin{abstract}
Trianto A, Radjasa OK, Sabdono A, Muchlissin SI, Afriyanto R, Sulistiowati, Radjasa SK, Crews P, Mccauley E. 2019. Exploration culturable bacterial symbionts of sponges from Ternate Islands, Indonesia. Biodiversitas 20: 776-782. Multidrug resistance, (MDR) bacteria seriously threaten human health which causes a more difficult and extends the treatment period, and increases the risk of death. Sponges-associated bacteria, a well known for their rich in chemical classes and bioactivities, are the prolific producers of bioactive compounds. In order to search new sources of antibacterial compounds, we collected a total of 55 sponges from Ternate Island that provided 324 bacterial isolates. The data showed that sponges-isolates ratio in the anthropogenic area was relatively higher than the other collection sites. The isolates were screened for the antibacterial activity against Klebsiella pneumoniae-RSDK, K. pneumoniae-UI, Pseudomonas aeruginosa A-UI, P. aeruginosa B-UI, Staphylococcus aureus-UI, MRSA-UI, MRPA-UI, Bacillus subtilis-RSDK, B. subtilis-UI, Salmonella typhi-UI, and MDR E. coli. The isolates were able to inhibit 0-7 the pathogenic bacteria on $24 \mathrm{~h}$ and $48 \mathrm{~h}$. The most active bacteria were identified as B. clausii, V. chiguensis, B. tropicus, P. marcusii, B. tropicus, V. parahaemolyticus, B. paramycoides, and $V$. dokdonensis. In conclusion, the sponges in the anthropogenic affected area have higher bacterial symbionts than that of in the pristine area. In this study, the results of isolation of the symbiont bacteria from sponge samples were obtained and morphologically observed for these bacterial isolates. The number of bacteria that were isolated were 133 bacterial isolates and ten isolates including producing active secondary metabolites
\end{abstract}

Keywords: Anthropogenic, bacteria, bioactive compounds, sponges, symbiont

\section{INTRODUCTION}

Multidrug resistance (MDR) bacteria are the pathogen that resistance to classical drugs by drug-inactivation or degradation and drug-target modification (Zwama and Yamaguchi 2018). The rising of MDR pathogen has been triggered by the unwise use of antibiotic by individual, physician, or hospital. The pathogenic MDR infection has been raising around the globe and became a serious threat to human health, which may incorporate with other diseases causes the more difficult treatment, extend the treatment period, and increases the risk of death (Yousefi et al. 2017).

The marine environment is the largest habitat representing more than $70 \%$ of the earth surface. Most part of the marine environments remains unexplored and underexploited in comparison with terrestrial ecosystems (Joint et al. 2010). Indonesia is the global epicenter of marine biodiversity with the megadiverse organisms that harbor the major of the Earth's species. Geographically, Ternate waters located in the meeting point of Australian and Indonesian plates rich the marine organisms diversity. Marine organisms and their micro-symbionts are the potential producers of bioactive secondary metabolites against pathogenic bacteria. Several bioactive compounds produced by invertebrates have been assumed produced by an associated microorganism of their host. Previous evidence (Burgess et al. 2003; Radjasa et al. 2011) revealed that microorganism which associated with marine organisms would synthesize the secondary metabolites that mimic produced by the host. Many researches have been focused on bacterial isolation derived from marine invertebrates, especially sponges which assumed to have secondary metabolites that have the ability against clinical pathogens or marine pathogens (Bell 2008). Among the unusual niches for novel microbes are sponges, which host hundreds of different bacterial groups and contain diverse symbionts. Studies have shed light on sponge-microbial relationships and provided evidence that sponges harbor diverse and biotechnologically valuable symbionts (Simister et al. 2012).

Sponges are one of the most potential marine biotic as the antibacterial compound resources. Sponge's bioactive compound has been used as drug resources such as antibacterial, antitumor, anticancer, antifungal, anti- 
inflammatory, cytotoxic, antimicrobial, antivirus, antimalarial, antifouling, and immunosuppressive (Mayer et al. 2010). As a whole, phylum Porifera possesses a striking level of taxonomic, genetic, and functional biodiversity. The taxonomic biodiversity of marine sponges and microbial symbionts is vast and only a small percentage of this biodiversity, i.e., relatively few case examples in proportion to the number of overall species of marine sponges in the world's oceans, has been described (Taylor et al. 2007). Overall, there is much to be learned from understanding nature's biodiversity. A deeper understanding of the groups of microorganisms is an important frontier for the discovery of new marine-derived small molecule scaffolds that will unveil new fields of discovery. It is therefore important to know the existence of sponge-associated bacteria and their potential, especially to prevent diseases caused by pathogenic bacteria (Wewengkang et al. 2014). The paper specifically reports the potential of marine bacteria derived from sponges with pharmacological potential against clinical pathogens.

The rising number of infection by MDR pathogens urge to the discovery of a new drug that led intensive exploration of bioactive compounds from the sea. However, most of the bioactive compounds available in a small concentration in the marine organisms that become an obstacle in drug development for decades (Pan et al.
2008; Raghukumar 2008; Schultz et al. 2008). Symbiotic systems in which there is a strong likelihood of bioactive microbial metabolite synthesis offer attractive alternatives to chemical synthesis or extraction from natural sources. Some microsymbionts such as bacteria and fungi, able to maintain their ability in the production of bioactive compounds in an artificial system. The microorganisms can be used in a fermentation system to produce the targeted compound in large scale continuously (Hildebrand et al. 2004).

\section{MATERIALS AND METHODS}

\section{Sponges collection and bacteria isolation}

The sponge specimens were collected on April 21-24 2018 in Ternate waters, North Maluku, Indonesia with SCUBA Diving from a depth of approximately 3-30 m. The collection sites were in Falajava beach, Taman Nukila, Big O1, Big O2, Tanjung Holl, and Taman Jikomolalo (Figure 1). The sponge specimen was kept in a coolbox with ice a until isolation of the bacteria process. A small part of each sponge was kept in $70 \%$ ethanol as a voucher for identification (Trianto et al. 2011).
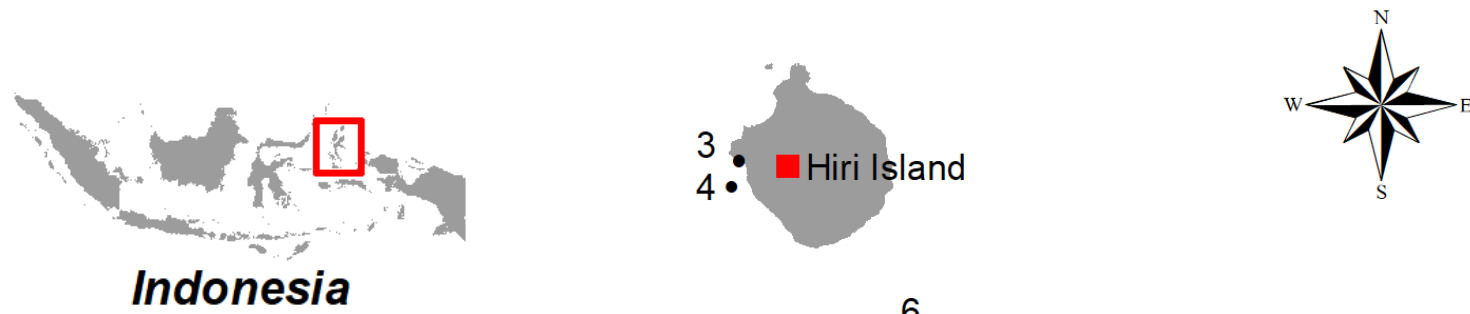

\section{Indonesia}
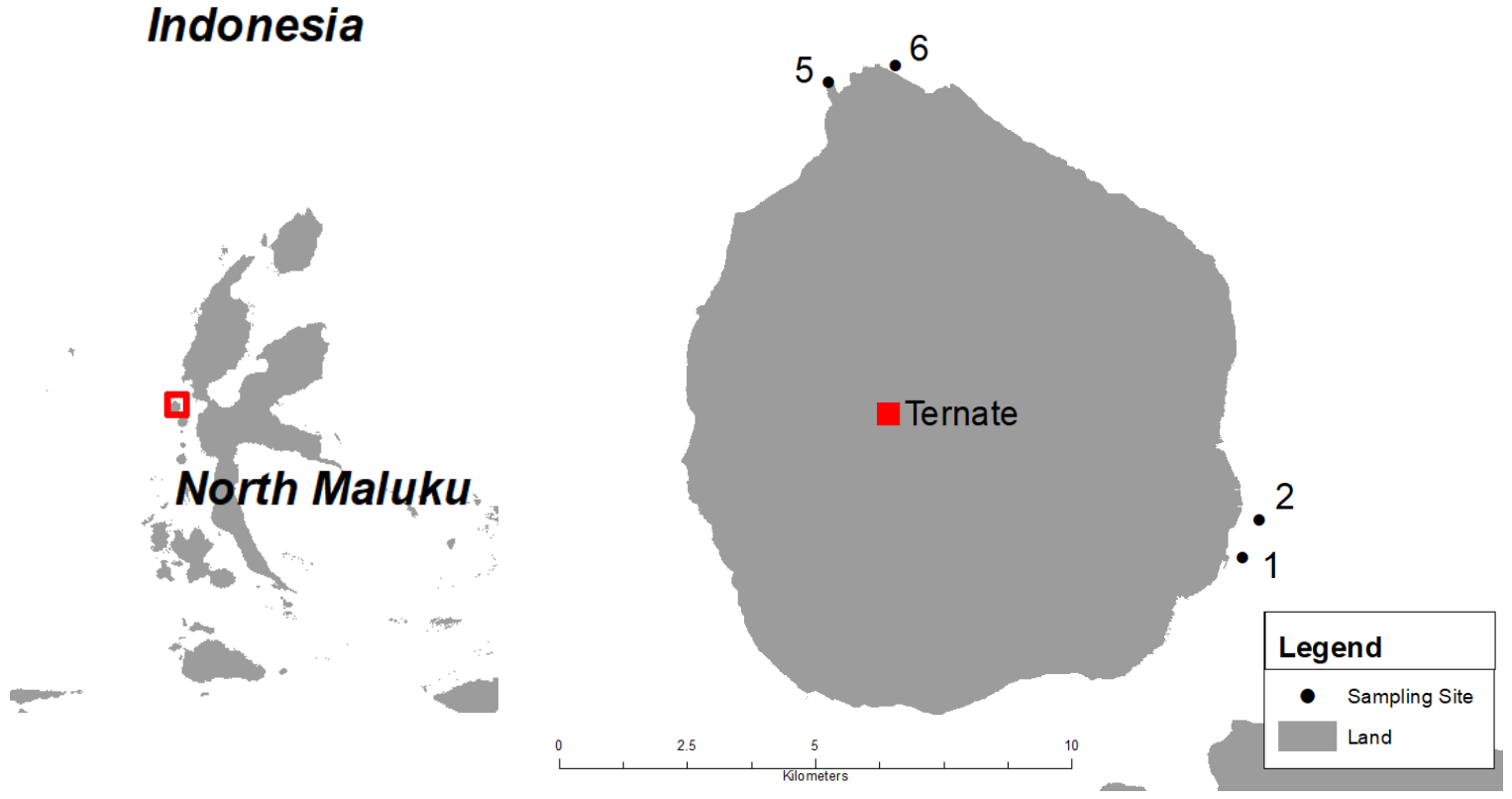

Figure 1. Research site in Ternate and Hiri Island, North Maluku (Moluccas) Province of Indonesia 
Isolation, purification, morphological identification, and bacterial screening were conducted in Tropical Marine Biotechnology, Integrated Central Laboratory of Diponegoro University, Semarang, Indonesia. The sponge specimens were washed using sterile seawater three times, to separate the impurities attached on the sponges surface. Bacterial isolation was done using the dilution method (10-1, 10-2, $10-3,10-4$ and 10-5). The bacteria were inoculated on the Zobell 2216E agar media from serial dilutions of 10-2, 10$3,10-4$ and $10-5$ and were incubated at $26^{\circ} \mathrm{C}$ for seven days. Each bacterial colonies grew on the plate was separated according to shape, elevation, and color. The pure colonies were kept in slant cultures at-20 0C (Radjasa et al. 2007).

\section{Gram test}

Gram tests were carried out by using a $\mathrm{KOH} 3 \%$ string test and Gram staining test. $\mathrm{KOH} \mathrm{3 \%}$ string test was done according to Ali et al. (2016); Dash and Payyappilli (2016), a loopful of a bacterial colony from the culture plate was emulsified over glass slide in suspension of $3 \% \mathrm{KOH}$. Gram staining test was done according to Ayuningrum (2017), using gram's staining solution A (crystal violet), solution B (lugol iodine), solution C (alcohol) and solution $\mathrm{D}$ (safranin).

\section{Antibacterial assay}

The sponge isolates were screened for the antibacterial activity against Klebsiella pneumoniae-RSDK, $K$. pneumoniae-UI, $P$. aeruginosa A-UI, $P$. aeruginosa B-UI, Staphylococcus aureus-UI, MRSA-UI, MRPA-UI, Bacillus subtilis-RSDK, B. subtilis-UI, Salmonella typhi-UI, and MDR E. coli. The pathogenic bacteria were obtained from the General Hospital Dr. Kariadi, Semarang, Central Java (RSDK) and from The Clinical Microbiology Laboratory, University of Indonesia (UI). All pathogenic strains were refreshed onto Zobell $2216 \mathrm{E}$ for $24 \mathrm{H}$ at $32^{\circ} \mathrm{C}$ before bioassay. The antibacterial assay was performed using two different methods, namely overlay, and disc diffusion methods (Sabdono and Radjasa 2006).

The antibacterial test was conducted using the overlay method on Zobell 2216E agar media and incubation at $37^{\circ} \mathrm{C}$ for $24 \mathrm{~h}$. The antibacterial test was conducted by mixing each test strain in soft agar media and pouring into the Petri dishes containing the bacterial colonies previously inoculated. The bacterial density was standardized using with a 0.5 McFarland. The test was performed in triplicates. The antibacterial activity was indicated by a clear zone around the isolated colony. The inhibition zones were observed at $24 \mathrm{~h}, 48 \mathrm{~h}$, and $72 \mathrm{~h}$.

Furthermore, the disc diffusion method was used for confirmation the bacterial isolates showed biological activity. At a glance, the method was conducted as follow: the pathogenic bacteria were cultured on 2216E Zobell agar media with streak method. By using a tweezer, the sterile paper disc was placed on the surface media that contains pathogenic bacteria. The bacterial isolates cultured in the 2216E Zobel liquid media for 1-2 days were taken as much as $10 \mu \mathrm{L}$ and dropped on paper disk $(6 \mathrm{~mm})$. The inhibition zone was observed every 24 hours during 2-day incubation.

\section{Bacteria identification}

The active bacteria isolates were cultured on $2216 \mathrm{E}$ Zobell media agar and incubated for two days at room temperature. DNA extraction was performed using Zymo bacteria/fungal DNA mini prep ${ }^{\mathrm{TM}}$ (Vesty et al. 2017). Primers used for PCR 16S rDNA amplification based on Lee, Jung et al. (2006); Susilowati (2015) were universal primer 27F (5'-AGAGTTTGATCMTGGCTCAG-3') and specific primer eubacteria 1492R (5'TACGGYTACCTTGTTACGACTT-3'). PCR condition was the following: denaturation at $95^{\circ} \mathrm{C}$ for 3 minutes, annealing at $53,9^{\circ} \mathrm{C}$ for 1 minute, extension $72^{\circ} \mathrm{C}$ for 1 minute, all followed by 30 cycles. The PCR products were examined using 1\% agarose gel electrophoresis and the result was visualized by using UVIDoc HD5 (UVITEC Cambridge).

\section{DNA sequencing and phylogenetic analysis}

The DNA sequencing was carried out in the PT. Genetika Science (Jakarta, Indonesia). The gene sequences were analyzed using the Basic Local Alignment Search Tool (BLAST) (Altschul et al. 1990). To identify different species, phylogenetic trees were constructed using the MEGA 7 with the 1000x bootstrap test. The results of BLAST Homology were deposited to the DNA Data Bank of Japan (DDBJ, www.ddbj.nig.ac.jp) in order to obtain the accession number. The phylogenetic tree was reconstructed using the MEGA 7 software package with the neighborjoining method and 1000 number of bootstrap replication (Tamura et al. 2011).

\section{RESULTS AND DISCUSSION}

\section{The sponges and isolates}

A total of 53 sponges were collected from 6 locations, i.e., Falajava Beach waters; Nukila Park; Big O and Bio O2 west of Hiri Island; Cape Holl; and Tanjung. In the Ternate water. The highest number sponges were obtained from the Falajava Beach, while Taman Nukila contributed the smallest number of the sponges. The number of culturable bacteria isolated were 324 from whole sponges where the Falajava Beach give the highest number of isolated followed by Big O1, Big O2, Taman Jikomolalo, Tanjung Hol, and Taman Nukila, respectively. However, Taman Nukila showed the highest isolates to sponges (I/S) ratio, while the Big $\mathrm{O} 1$ has the lowest I/S ratio (Table 1).

Sponges are well known to associate with a remarkable number of different microorganisms phyla including Gamma and Alpha-proteobacteria, Actinobacteria, Chloroflexi, Nitrospirae, Cyanobacteria, Entotheonella the candidate phylum "Poribacteria," "Thaumarchaea," and "Tectobacteria" (Schmitt et al. 2012; Taylor et al. 2013; Reveillaud et al. 2014; Wilson et al. 2014; Webster and Thomas 2016; Steinert et al. 2017). The levels of richness and diversity of these symbiont communities vary widely between sponge species, most of which are considered metabolically active (Kamke et al. 2010; Webster and Thomas 2016). Some microorganisms that live associated with sponge identified as marine sponge body provides a 
suitable habitat for the microbes by giving space, nutrient, and chemical substances. Some sponge has specific associate bacteria; however, most of the sponges have abundance of associated bacteria (Mehbub et al. 2014). The sponge has a higher effect on shaping or bacterial composition than the environment (Fabio et al. 2017).

\section{Screening to the antibacterial activities}

Overlay test of 133 out of 324 the bacterial isolates from the Ternate waters showed that each pathogen strain has different susceptibility to the isolates. $S$ aureus was the most vulnerable to the isolates that 31 of them able to inhibit it on $24 \mathrm{~h}$ and $48 \mathrm{~h}$. On the other hand, MRSA, an MDR $S$. aureus strain, was less susceptible, which only 13 and 12 isolates able to inhibit it on $24 \mathrm{~h}$ and $48 \mathrm{~h}$. Interestingly, E. coli was resistant to the whole isolates. Most of the pathogen acquire the resistance to the isolates on $72 \mathrm{~h}$ of incubation. However, few of the pathogen have unable to develop the resistance to the isolates. $K$. pneumoniae-RSDK Staphylococcus aureus-UI, and MRSA-UI were the best example of the resistance development by the pathogenic bacteria (Table 2). Even in the case of $S$. typhi the longer incubation time the more susceptible to isolates. Surprisingly, the source or strain of the pathogen has a high consequence on the resistance to the isolates that indicated the different level of resistance to bioactive compounds.

The ability of bacteria to adaptation or neutralize the drug or other chemical effects highly depend on the presence of the resistance gene. For example; the ermB gene in Clostridium difficile play an important role in confers resistance to macrolides, lincosamides and streptogramin B (MLSB) antibiotics. Another gene, the tet $M$ encoding resistance to tetracyclines (Spigaglia 2016). Other study showed that $C$. difficile bears the gyrA and gyrB genes responsible for mediating the mutations for fluoroquinolone resistance (Chatedaki et al. 2019). Further research revealed that bacteria and bacterial genes often could move between all three compartments, in any direction (Woolhouse et al. 2015; Martinez 2018).

Base on screening result, we obtained the best 10 of the isolates that had a strong activity to the MDR bacterial pathogens. Three isolates, TE-TN-01.3 TE-TN-01.6, and TE-TN-02.5, isolated from the sponges collected in Taman Nukila water had a strong activity to 2,3 , and 4 pathogens, respectively. Four other isolates obtained from the Big O1 and $\mathrm{O} 2$ waters, TE-BO-11, TE-BO-15.2, TE-BO2-01.7 and TE-BO2-04.2, had the highest bioactivity in the first 24 hours, both isolates could inhibit seven types of pathogenic bacteria (MRPA, MRSA, P. aeruginosa, Salmonella typhi, Bacillus subtilis, and Klebsiella pneumoniae). The TE-PF08.7 and TE-TJ-01.5 that isolated from sponges collected from Pantai Falajava and Taman Jikomolalo, respectively, also had a strong activity to the 3 and 2 pathogens, respectively (Table 3). This study incorporated with another study on soil bacteria alluded that the bacteria isolate able to inhibited between 0-4 antagonistic bacteria (Gislin et al. 2018). Another study on sponge-associated bacteria has also indicated that the isolates have different ability to inhibit the antagonistic bacteria (Cita et al. 2017).
The finding of a new source of antibiotic agents that kill resistant bacteria is urgently required due to the rising of MDR pathogenic bacteria (Lee et al. 2019).

Table 1. The number of sponges collected from various locations in Ternate and the number of bacteria isolates isolated from the sponge

\begin{tabular}{lccc}
\hline Collection site & $\begin{array}{c}\text { Sponge } \\
\text { number }\end{array}$ & $\begin{array}{c}\text { Isolates } \\
\text { number }\end{array}$ & $\begin{array}{c}\text { Isolates/ } \\
\text { sponges ratio }\end{array}$ \\
\hline Falajava Beach & 15 & 95 & 6.3 \\
Taman Nukila & 2 & 21 & 10.5 \\
Big O1 & 15 & 73 & 4.9 \\
Big O2 & 8 & 52 & 6.5 \\
Tanjung Hol & 8 & 41 & 5.1 \\
Taman Jikomolalo & 7 & 42 & 6.0 \\
Total/average & 55 & 324 & 5.9 \\
\hline
\end{tabular}

Table 2. The active isolates against various pathogenic bacteria

\begin{tabular}{|c|c|c|c|}
\hline \multirow{2}{*}{ Pathogenic bacteria } & \multicolumn{3}{|c|}{ Number of active isolates } \\
\hline & $24 \mathrm{H}$ & $48 \mathrm{H}$ & $72 \mathrm{H}$ \\
\hline K. pneumoniae-RSDK & 7 & 7 & 3 \\
\hline K. pneumoniae-UI & 2 & 2 & 2 \\
\hline P. aeruginosa A-UI & 0 & 0 & 1 \\
\hline P. aeruginosa B-UI & 4 & 6 & 3 \\
\hline Staphylococcus aureus-UI & 31 & 31 & 14 \\
\hline MRSA-UI & 13 & 12 & 5 \\
\hline MRPA-UI & 13 & 11 & 3 \\
\hline B. subtilis-RSDK & 12 & 1 & 0 \\
\hline B. subtilis-UI & 10 & 12 & 12 \\
\hline Salmonella typhi-UI & 5 & 13 & 17 \\
\hline E. coli & 0 & 0 & 0 \\
\hline
\end{tabular}

Note: Escherichia coli, Klebsiella pneumoniae, MRPA, MRSA, P. aeruginosa, Salmonella typhi, Staphylococcus aureus, Bacillus subtilis are pathogenic bacteria used for screening bacterial isolates. The code in the sign " ()" is the variety or origin of the pathogenic bacteria.

Table 3. Best isolates against pathogen bacteria

\begin{tabular}{lllllllllllllll}
\hline \multirow{2}{*}{ Isolates code } & \multicolumn{10}{c}{ Activity against the pathogenic bacteria } & Pathogen \\
\cline { 2 - 10 } & A & B & C & D & E & F & G & H & I & J & K & inhibited \\
\hline TE-TN-01.3 & - & - & + & - & - & - & - & + & - & - & - & 2 \\
TE-TN-01.6 & - & + & + & + & - & - & - & - & - & - & - & 3 \\
TE-TN-02.5 & - & + & + & - & - & - & - & + & - & + & - & 4 \\
TE-BO-11.4 & - & - & - & + & - & - & - & - & - & - & - & 1 \\
TE-BO-15.2 & - & - & + & + & - & + & + & + & - & + & - & 6 \\
TE-PF-08.7 & - & - & - & - & - & - & + & - & + & + & - & 3 \\
TE-BO2-01.7 & - & - & + & + & - & + & + & - & - & + & + & 6 \\
TE-BO2-01.10 & - & + & + & + & - & + & + & - & - & + & - & 6 \\
TE-BO2-04.2 & - & + & + & - & - & + & + & - & - & + & + & 6 \\
TE-TJ-01.5 & - & - & + & - & - & - & - & + & - & - & - & 2 \\
\hline
\end{tabular}

Note: Symbion Sponge isolates bacteria code, TE-TN: Sponge sample from Taman Nukila waters, TE-PF: Sponge sample from Falajava beach, TE-BO: Sponge sample from Big O waters, TE$\mathrm{BO} 2$ : Sponge sample from Big O2 waters, TE-TJ: Sponge sample from Taman Jikomalamo.waters. Pathogen bacteria: A. E. coli, B. Klebsiella pneumoniae A, C. MRPA, D. MRSA E. P. aeruginosa A, F. P. aeruginosa B, G. Salmonella typhi, H. Staphylococcus aureus, I. Bacillus subtilis A J. Bacillus subtilis B, K. Klebsiella pneumoniae B. 


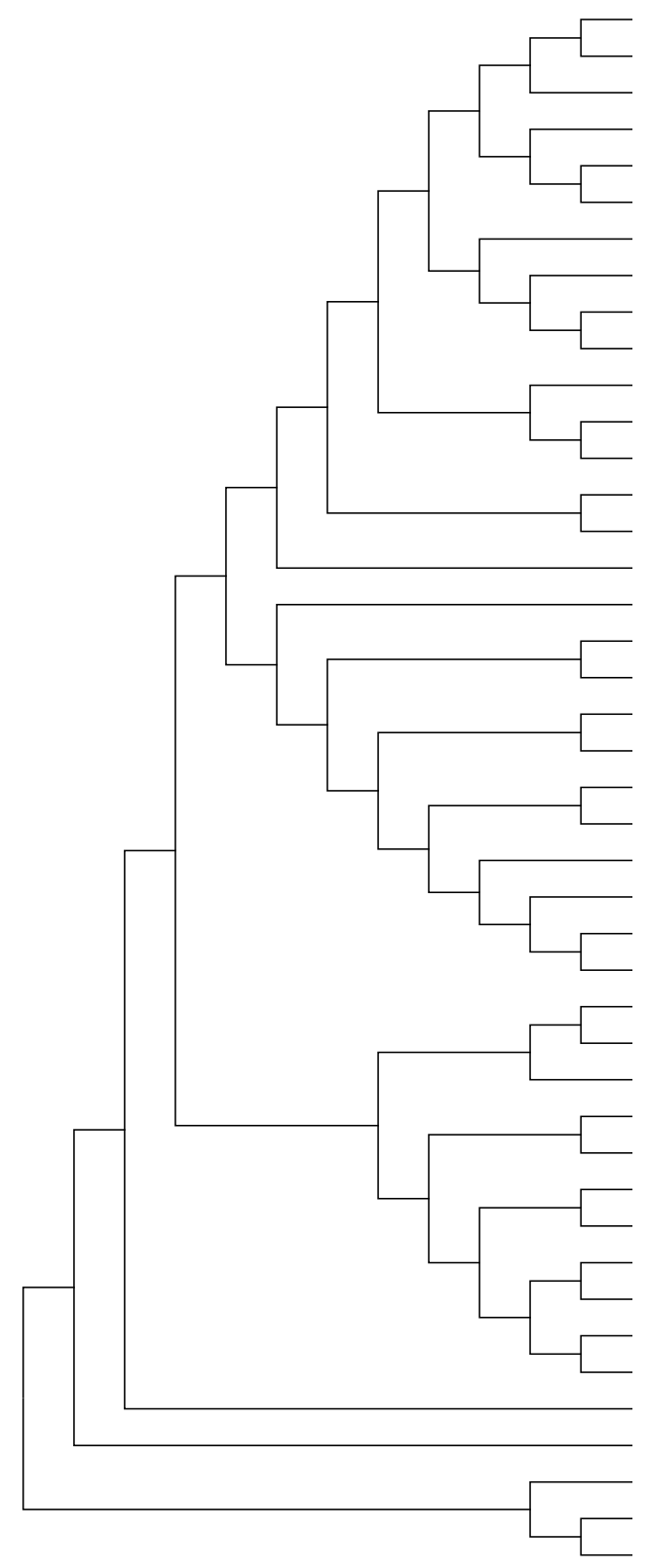

TE-BO-15.2

NR_122050.1 Vibrio alginolyticus strain NBRC 15630 NR_121709.1 Vibrio alginolyticus strain NBRC 15630 NR_118258.1 Vibrio alginolyticus strain ATCC 17749 NR_041838.1 Vibrio parahaemolyticus strain ATCC 17802 NR_113604.1 Vibrio parahaemolyticus strain NBRC 12711 NR_157668.1 Paracoccus hibiscisoli strain THG-T2.31 NR_044922.1 Paracoccus marcusii strain MH1 NR_024658.1 Paracoccus carotinifaciens strain E-396 NR_025714.1 Paracoccus haeundaensis strain BC74171 NR_133980.1 Bacillus shacheensis strain HNA-14 NR_026140.1 Bacillus clausii strain DSM 8716 NR_108311.1 Bacillus rhizosphaerae strain SC-N012 NR_029304.1 Halobacillus litoralis strain SL-4 DQ888316.1 Halobacillus mangrovi strain MS10 JN791304.1 Bacillaceae sp. BM04 16S NR_157736.1 Bacillus tropicus strain MCCC 1A01406 NR_157729.1 Bacillus albus strain MCCC 1A02146 NR_112630.1 Bacillus cereus strain NBRC 15305 NR_157734.1 Bacillus paramycoides strain MCCC 1 A04098 TE-TJ-01.5

NR_074540.1 Bacillus cereus strain ATCC 14579 NR_157730.1 Bacillus luti strain MCCC 1A00359 NR_157732.1 Bacillus nitratireducens strain MCCC 1 A00732 TE-TN-02.5

NR_157729.1 Bacillus albus strain MCCC 1A02146 TE-BO-11.4

NR_043402.1 Virgibacillus pantothenticus strain IAM 11061 NR_114091.1 Virgibacillus pantothenticus strain NBRC 102447 NR_115602.1 Virgibacillus pantothenticus strain IAM11061 NR_028873.1 Virgibacillus marismortui strain 123 TE-BO2-04.2 TE-BO2-01.10 NR_044086.1 Virgibacillus chiguensis strain NTU-101 TE-TN-01.6 TE-BO2-01.7 NR_043206.1 Virgibacillus dokdonensis strain DSW-10 NR_043572.1 Virgibacillus olivae strain E308 NR_025308.1 Virgibacillus proomii strain LMG 12370 NR_144700.1 Virgibacillus massiliensis strain Vm-5 NZ_JWIQ02000160.1 Bacillaceae bacterium MTCC 10057 TE-TN-01.3

TE-PF-08.7

Figure 2. The phylogenic relationship of potential endophytic and nearest species of bacteria on 16R sRNA sequences by using Neighbor-Joining (NJ) methods.

Table 1. The similarity of the 16S rRNA gene sequences of potential endophytic bacteria from sponges using BLAST-N at NCBI

\begin{tabular}{|c|c|c|c|c|c|}
\hline Isolate code & $\begin{array}{c}\text { Basepairs } \\
\text { length }\end{array}$ & Nearest species & $\begin{array}{c}\text { Percentage } \\
\text { cover }\end{array}$ & $\begin{array}{c}\text { Percentage } \\
\text { similarity }\end{array}$ & Access no. \\
\hline TE-TN-01.3 & $1142 \mathrm{bp}$ & Bacillus clausii strain DSM 8716 & $97 \%$ & $97 \%$ & NR_026140.1 \\
\hline TE-TN-01.6 & 1434 bp & Virgibacillus chiguensis strain NTU-101 & $100 \%$ & $99 \%$ & NR_044086.1 \\
\hline TE-TN-02.5 & $690 \mathrm{bp}$ & Bacillus tropicus strain MCCC 1A01406 & $100 \%$ & $99 \%$ & NR_157736.1 \\
\hline TE-PF-08.7 & 1224 bp & Paracoccus marcusii strain MH1 & $98 \%$ & $86 \%$ & NR_044922.1 \\
\hline TE-TJ-01.5 & 804 bp & Bacillus tropicus strain MCCC 1A01406 & $100 \%$ & $99 \%$ & NR_157736.1 \\
\hline TE-BO-15.2 & 1391 bp & Vibrio parahaemolyticus strain ATCC 17802 & $100 \%$ & $99 \%$ & NR_041838.1 \\
\hline TE-BO-11.4 & 1309 bp & Bacillus paramycoides strain MCCC 1A04098 & $100 \%$ & $99 \%$ & NR_157734.1 \\
\hline TE-BO2-01.7 & 1439 bp & Virgibacillus dokdonensis strain DSW-10 & $100 \%$ & $99 \%$ & NR_043206.1 \\
\hline TE-BO2-01.10 & 1438 bp & Virgibacillus dokdonensis strain DSW-10 & $100 \%$ & $99 \%$ & NR_043206.1 \\
\hline TE-BO2-04.2 & $1413 \mathrm{bp}$ & Virgibacillus dokdonensis strain DSW-10 & $100 \%$ & $99 \%$ & NR_043206.1 \\
\hline
\end{tabular}


Identification of the active isolates based on $16 \mathrm{~S}$ rRNA

Marine sponges are known to be important sources of novel marine natural products. Sponge-associated microorganisms represent a treasure house of biodiversity for the discovery of marine natural products with biotechnological potential (Mohan et al. 2016). The isolate of 16S rRNA gene was analyzed by electrophoresis (Clever Scientific) of agarose gel $1 \%(\mathrm{c} / \mathrm{v})$ and used DNA Ladder (Geneaid®) to know that $16 \mathrm{~S}$ rRNA gene fragment size is $\pm 1300 \mathrm{bp}$. The Identification of potential endophytic bacteria is based on 16S rRNA gene sequences similarity percentage < $95 \%$ indicates same family, similarity percentage $\geq 95 \%$ to $<99 \%$ indicates the same genus, and similarity percentage $\geq 99 \%$ indicates same species (Bosshard et al. 2003) Based on those criteria, that one of ten isolated bacteria has a low similarity (TE-PF-08.7). Moreover, eight isolates of potential endophytic bacteria having high similarity $\geq 99 \%$ they are TE-TN-01.6, TE-TN02.6, TE-TJ-01.5, TE-BO-15.2, TE-BO2-01.7, TE-BO201.10, TE-BO2-04.2, TE-BO-11.4, and one isolate has criteria indicated the same genus with percentage $\geq 95 \%$ to $<99 \%$ (TE-TN-01.3) (Figure 2).

According to Pangastuti (2006), if the similarity degree of the sequencing of 16 rRNA gene less than $97 \%$, it can be considered as a new species. Moreover, TE-PF-08.7 isolate has a similarity with the bacteria family Rhodobacteraceae. The genus Paracoccus belongs to Gram-negative bacteria, cocci or short rods that show substantial metabolic versatility. Representatives are able to grow aerobically on a wide range of organic compounds. Some species can also grow anaerobically, using nitrate as electron acceptor, and some representatives can use hydrogen as an electron donor for chemoautotrophic growth. Phylogenetically, the genus belongs to the $a-3$ subclass of the Proteobacteria. Cocci to short rods, $1-2$ by $1.0-13 \mathrm{pm}$ in size, growing in pairs or short chains. Non-motile. Colonies on agar are flat, smooth and bright orange, due to the accumulation of carotenoids, including astaxanthin (Herker et al. 1998).

TE-BO-15.2 isolate has a similarity with bacteria $V$. parahaemolyticus from a marine sponge. According to by (Ulitzur 1974; Molitoris 1985) Vibrio parahaemolyticus and several species occur in estuarine or coastal environment zone of the oceans, mainly as contaminants of different shellfish and absolutely to become dominant species in environments. TE-BO2-01.7, TE-BO2-01.10, TE-BO2-04.2 isolate have a similarity with $V$. dokdonensis. Genus Virgibacillus, which was first reported by (Heyndrickx et al. 1998) as originally designated from Bacillus spp. Huang et al. 2018 reported Virgibacillus dokdonensis from deep sea water in the East Pacific Ocean had produced bioactive secondary metabolites inhibiting pathogens Xanthomonas oryzae.

In conclusion, a total of 324 bacteria were isolated from 55 sponge specimens collected from six stations in Ternate Water. The isolates showed activity against of MDR pathogenic bacteria including Klebsiella pneumoniaeRSDK, $K$. pneumoniae-UI, $P$. aeruginosa A-UI, $P$. aeruginosa B-UI, Staphylococcus aureus-UI, MRSA-UI, MRPA-UI, Bacillus subtilis-RSDK, B. subtilis-UI,
Salmonella typhi-UI, and MDR E. coli. The best ten isolates, TE-TN-01.3, TE-TN-01.6, TE-TN-02.5, TE-PF08.7, TE-TJ-01.5, TE-BO-15.2, TE-BO-11.4, TE-BO201.7, TE-BO2-01.10, TE-BO2-04.2 identified as B. clausii, $V$. chiguensis, B. tropicus, P. marcusii, B. tropicus, V. parahaemolyticus, B. paramycoides, and $V$. dokdonensis, respectively.

\section{ACKNOWLEDGEMENTS}

This work was mainly supported by a PEER research grant (NAS Subwared Letter No. 200007644) under Prime Agreement Number AID-OAA-A-11-00012 between NAS and USAID.

\section{REFERENCES}

Ali N, Zada A, Ali M, Hussain Z. 2006. Isolation of Agrobacterium Turmefaciens from the Galls of Peach Tree. J Rural Dev Agric 1 (1): 39-48.

Altschul SF, Gish W, Miller W, Myers EW, Lipman DJ, Pennsylvania T, Park U. 1990. Basic Local Alignment Search Tool 2. Department of Computer Science. J Mol Biol 215 (3): 403-410. DOI: 10.1016/S0022-2836 (05)80360-2

Ayuningrum D, Kristiana R, Asagabaldan MA, Sabdono A, Radjasa OK, Nuryadi H, Trianto A. 2017. Isolation, characterization and antagonistic activity of bacterial symbionts hard coral Pavona sp. isolated from Panjang Island, Jepara against infectious multi-drug resistant (MDR) bacteria. IOP Conf Ser Earth Environ Sci 55 (1): DOI: $10.1088 / 1755-1315 / 55 / 1 / 012029$.

Bell JJ. 2008. The functional roles of marine sponges. Estuarine Coastal Shelf Sci 79: 341-353.

Bosshard PP, Abels S, Zbinden R, Bottger ECB, Altwegg M. 2003. Ribosomal DNA sequencing for identification of aerobic Grampositive rods in the Clinical Laboratory (an 18 Month Evaluation). J Clin Microbiol 41: 4134-4140.

Burgess JG, Boyd KG, Amstrong E, Jiang Z, Yan L, Berggren M, May U, Pisacane T, Granmo A, Adams DR. 2003. Development of a marine natural product-based antifouling paint. Biofouling 19: 197-205.

Chatedaki C, Voulgaridi I, Kachrimanidou M, Hrabak J, Papagiannitsis CC. 2019. Antimicrobial susceptibility and mechanisms of resistance of Greek Clostridium difficile clinical isolates. J Global Antimicrob Res 16 (2019) 53-58. DOI: 10.1016/j.jgar.2018.09.009

Chatedaki C, Voulgaridi I, Kachrimanidou M, Hrabak J, Papagiannitsis CC, Petinaki E. 2019. Antimicrobial susceptibility and mechanisms of resistance of Greek Clostridium difficile clinical isolates. J Global Antimicrob Resist 16: 53-58.

Cita YP, Suhermanto A, Radjasa OK, Sudharmono P. 2017. Antibacterial activity of marine bacteria isolated from sponge Xestospongia testudinaria from Sorong, Papua. Asian Pac J Trop Biomed 7 (5): 450-454.

Dash C, Payyappilli RJ. 2016. KOH string and Vancomycin susceptibility test as an alternative method to Gram staining. J Intl Med Dent 3 (2): 88-90. DOI: 10.18320/JIMD/201603.0288

Gislin D, Sudarsanam D, Raj GA, Baskar K. 2018. Antibacterial activity of soil bacteria isolated from Kochi, India and their molecular identification. J Genet Eng Biotechnol 16: 287-294.

Harker M, Hirschberg J, Oren A. 1998. Paracoccus marcusii sp. nov, an orange Gram-negative coccus. Intl J Syst Bacteriol 48: 543-548

Hentschel U, Piel J, Degnan SM, Taylor MW. 2012. Genomic insights into the marine sponge microbiome. Nature Rev Microbiol 10 (9): 641-654. DOI: 10.1038/nrmicro2839

Heyndrickx M, Lebbe L, Kersters K, De Vos P, Forsyth G, Logan NA. 1998. Virgibacillus: A new genus to accommodate Bacillus pantothenticus (Proom and Knight 1950). Amended description of Virgibacillus pantothenticus. Int J Syst Bacteriol 48: 99-106. 
Hildebrand M, Waggoner LE, Lim GE, Sharp KH, Ridley CP, Haygood MG. 2004. Approaches to identify, clone, and express symbion bioactive metabolite genes. Nat Prod Rep 21 (1): 122-142. DOI: 10.1039/b302336m

Hooper JNA. 2003. Sponge guides: Guide to Spons Collection and Identification. Queensland Museum, Brisbane, Australia.

Huang D, Shao Z, YuY, Cai M, Zheng L, Li G, Yu Z, Yi X, Hoa F. 2018 Identification, Characteristics and Mechanism of 1-Deoxy-Nacetylglucosamine from Deep-Sea Virgibacillus dokdonensis MCCC 1A00493. Mar Drugs 16: 52. DOI: 10.3390/md16020052

Joint I, Mühling M, Querellou J. 2010. Culturing marine bacteria-An essential prerequisite for biodiscovery: Minireview. Microb Biotechnol 3 (5): 564-575. DOI: 10.1111/j.1751-7915.2010.00188.

Kamke J, Taylor MW, Schmitt S. 2010. Activity profiles for marine sponge-associated bacteria obtained by $16 \mathrm{~S}$ rRNA vs $16 \mathrm{~S}$ rRNA gene comparisons. ISME J 4 (4): 498-508. DOI: 10.1038/ismej.2009.143

Lee YK, Jung HJ, Lee HK. 2006. Marine bacteria associated with the Korean brown alga, Undaria pinnatifida Marine Bacteria Associated with the Korean Brown Alga, Undaria pinnatifida. J Microbiol 44 (6): 694-698

Lee J, Kim S, Sim JY, Lee D, Kim HH, Hwang JS, Lee DG, Park ZY, Kim JI. 2019. A potent antibacterial activity of new short Denantiomeric lipopeptide against multi-drug resistant bacteria. BBABiomembr 1861: 34-42.

Woolhouse M, Ward M, van Bunnik B, Farrar J. 2015. Antimicrobial resistance in humans, livestock and the wider environment. Phil Trans R Soc Lond Ser B Biol Sci 370

Mayer AMS, Glaser KB, Cuevas C, Jacobs RS, Kem W, Little RD, Shuster DE. 2010. The odyssey of marine pharmaceuticals: a current pipeline perspective. Trends Pharmacol Sci 31 (6): 255-265. DOI: 10.1016/j.tips.2010.02.005

Martinez JL. 2018. Ecology and evolution of chromosomal gene transfer between environmental microorganisms and pathogens. Microbiol Spectr 6 (1): 1-16.

Mehbub MF, Lei J, Franco C, Zhang W. 2014. Marine sponge-derived natural products between 2001 and 2010: trends and opportunities for discovery of bioactives. Mar Drugs 12: 4539-4577.

Mohan G, Thangappanpillai AKT, Ramasamy B. 2016. Antimicrobial activities of secondary metabolites and phylogenetic study of sponge endosymbiotic bacteria, Bacillus sp. at Agatti Island, Lakshadweep Archipelago. Biotechnol Reports 11 (2016): 44-52

Molitoris E, Joseph SW, Krichevsky MI, Sindhuhardja W, Colwell RR. 1985. Characterization and Distribution of Vibrio alginolyticus and Vibrio parahaemolyticus isolated in Indonesia. Applied and Environ Microbiol (50) 1388-1394. DOI: 0099-2240/85/121388-07\$02.00/0

Pan Z, Agarwal AK, Xu T, Feng Q, Baerson SR, Duke SO, Rimando AM 2008. Identification of molecular pathways affected by pterostilbene a natural dimethyl ether analog of resveratrol. BMC Med Genom 1 (1): 7. DOI: $10.1186 / 1755-8794-1-7$.

Pangastuti A. 2006. Species definition of prokaryotes based on 16S rRNA and protein-coding genes sequence. Biodiversitas 7: 292-296.

Radjasa OK, Sabdono A. 2003. Screening of secondary metabolite producing bacteria associated with coral using 16S rDNA-based approach. J Coast Dev 7 (1): 11-19.

Radjasa OK, Salasia SIO, Sabdono A, Weise J, Imhoff JF, Lammler C, Risk MJ. 2007. Antibacterial Activity of Marine Bacterium Pseudomonas sp. Associated with Soft Coral Sinularia polydactyla against Streptococcus equi Subsp. zooepidemicus. Intl J Pharmacol 3 (2): 170-174.

Radjasa OK, Sabdono A, Duhita SK, Rory AH, Lestari ES. 2007. Antibacterial activity of marine bacteria associated with sponge Aaptos sp. against Multi Drugs Resistant (MDR) strains. Jurnal Matematika dan Sains 12 (4):-

Radjasa OK, Martens T, Grossart HP, Brinkoff T, Sabdono A, Simon M 2007. Antagonistic activity of a marine bacterium Pseudoalteromonas luteoviolacea TAB4.2 associated with coral Acropora sp. J Biol Sci 7 (2): 239-246.

Reveillaud J, Maignien L, Eren MA, Huber JA, Apprill A, Sogin M. L, Vanreusel A. 2014. Host-specificity among abundant and rare taxa in the sponge microbiome. ISME J 8 (6): 1198-1209. DOI: 10.1038/ismej.2013.227

Raghukumar C. 2008. Marine fungal biotechnology: An ecological perspective. Fungal Div 31: 19-36.

Sabdono A, Radjsa OK. 2006. Anti-bacterial property of coral-associated bacterium Bacillus sp. against coral pathogenic Black Band Disease (BBD). J Coastal Dev 9 (3): 175-182.

Sardiani N, Litaay M, Budji RG, Priosambodo D, Syahribulan, Dwyana Z . 2015. Potensi tunikata Rhopaleae sp. sebagai sumber inokulum bakteri endosimbion penghasil antibakteri: 1. Karakteristik Isolat. Jurnal Alam dan Lingkungan 6 (11): -. [Indonesian]

Schmitt MW, Kennedy SR, Salk JJ, Fox EJ, Hiatt JB, Loeb LA. 2012. Detection of ultra-rare mutations by next-generation sequencing. Proc Natl Acad Sci USA 109 (36): 14508-14513. DOI: 10.1073/pnas.1208715109.

Schultz PW, Khazian AM, Zaleski AC. 2008. Using normative social influence to promote conservation among hotel guests. Soc Influen 3 (1): 4-23. DOI: $10.1080 / 15534510701755614$

Simister R, Deines P, Botte ES, Webster NS, Taylor M W. 2012. Spongespecific clusters revisited: a comprehensive phylogeny of spongeassociated microorganisms. Environ Microbiol 14 (2): 517-520. DOI: 10.1111/j.1462-2920.2011.02664.x

Spigaglia P. 2012. Recent advances in the understanding of antibiotic resistance in Clostridium difficile infection. Ther Adv Infect Dis 3 (1). DOI: $10.1177 / 2049936115622891$

Steinert G, Rohde S, Janussen D, Blaurock C, Schupp P J. 2017. Hostspecific assembly of sponge-associated prokaryotes at high taxonomic ranks. Sci Rep 7 (1): 1-9. DOI: 10.1038/s41598-017-02656-6

Susilowati R, Sabdono A, Widowati I. 2015. Isolation and characterization of bacteria associated with brown algae Sargassum spp. from Panjang Island and their antibacterial activities. Procedia Environ Sci 23 (Ictcred 2014): 240-246. DOI: 10.1016/j.proenv.2015.01.036

Tamura K, Peterson D, Peterson N, Stecher G, Nei M, Kumar S. 2011. MEGA5: Molecular evolutionary genetics analysis using maximum likelihood, evolutionary distance, and maximum parsimony methods. Mol Biol Evol 28 (10): 2731-2739. DOI: 10.1093/molbev/msr121

Taylor MW, Radax R, Steger D, Wagner M. 2007. Sponge-associated microorganisms: evolution, ecology, and biotechnological potential. Microb Mol Biol Rev 71 (2): 295-347. DOI: 10.1128/MMBR.0004006

Trianto A, Hermawan I, De Voogd NJ, Tanaka J. 2011. Halioxepine, A new meroditerpene from an Indonesian sponge Haliclona sp. Chem Pharm Bull 59 (10): 1311-1313.

Ulitzur S. 1974. Vibrio parahaemolyticus and Vibrio alginolyticus short generation-time marine bacteria. Microb Ecol 1: 127-135.

Vesty A, Biswas K, Taylor M W, Gear K, Douglas RG. 2017. Evaluating the impact of DNA extraction method on the representation of human oral bacterial and fungal communities. PLoS ONE 12 (1): 1-13. DOI: 10.1371/journal.pone.0169877

Webster NS, Thomas T. 2016. Defining the sponge hologenome. MBio 7 (2): e00135-16. DOI: 10.1128/mBio.00135-16.Invited

Wewengkang DS, Sumilat DA, Rotinshu H. 2014. Karakterisasi dan bioaktif antibakteri senyawa spons Haliclona sp. dari Teluk Manadao. Jurnal LPPM Bidang Sains dan Teknologi 1: 71-85. [Indonesian]

Wilson J, Gabriel L, James H. 2014. Observing a client's grieving process: bringing logical positivism into qualitative grief counseling research. $\mathrm{Br} \mathrm{J}$ Guid Counsel 42 (5): 568-583. DOI: 10.1080/03069885.2014.936823

Woolhouse M, Ward M, Bunnik B, Farrar J. 2015. Antimicrobial resistance in humans, livestock and the wider environment. Phil Trans R Soc B 370: 20140083. DOI: 10.1098/rstb.2014.0083

Yousefi M, Dadashpour M, Hejazi M, Hasanzadeh M, Behnam B, de la Guardia M, Shadjou N, Mokhtarzadeh A. 2017. Anti-bacterial activity of graphene oxide as a new weapon nanomaterial to combat multidrug-resistance bacteria. Mater Sci Eng C 74: 568-581. DOI: 10.1016/j.msec.2016.12.125

Zwarna M, Yamaguchi A. 2018. Molecular mechanisms of AcrBmediated multidrug export. Res Microbiol. DOI: 10.1016/j.resmic.2018.05.005 